\title{
Why transaction costs are so relevant in political governance? A new institutional survey
}

\author{
Por que os custos de transação são tão relevantes na \\ governança política? Uma nova pesquisa institucional
}

GONZALO CABALLERO

DAVID SOTO-OÑATE*

RESUMO: A Nova Economia Institucional, liderada por quatro ganhadores do Prêmio Nobel (Ronald Coase, Douglass North, Oliver Williamson e Elinor Ostrom), mostrou que as instituições e organizações são um meio para reduzir os custos de transação e obtenção de maior eficiência no desempenho econômico. Este artigo examina o programa da Nova Economia Institucional para explicar a importância dos custos de transação em intercâmbio político e organização, e mostrar que os custos são maiores nos mercados políticos do que nos mercados econômicos. $\mathrm{O}$ artigo analisa as principais contribuições sobre transação política e de governança. A pesquisa inclui o catálogo mais detalhado que já foi publicado dos custos políticos de transação.

PALAVRAS-CHAVE: Intercâmbio político; custos de transação; instituições; organização política; governança.

ABSTRACT: The New Institutional Economics, led by four Nobel laureates (Ronald Coase, Douglass North, Oliver Williamson and Elinor Ostrom), has showed that institutions and organizations are a medium for reducing transaction costs and obtaining a higher efficiency in economic performance. This paper goes into the research program of the New Institutional Economics to explain the relevance of transaction costs in political exchange and organization and show that transactions costs are even higher in political markets than in economic markets. The paper reviews the main contributions on institutions, transaction costs and political governance, and provides some lessons on political transacting and governance. The survey includes the most detailed catalogue of political transaction costs that has ever been published. KEYWORDS: political exchange; transaction costs; institutions; political organization; governance.

JEL Classification: B52; P48.

\footnotetext{
* Associate Professors of Economics at the Universidade de Vigo, Spain, e-mails: gcaballero@uvigo.es; davidsoto@uvigo.es. Submitted: 8/July/2014; Approved: 16/July/2015.
} 


\section{INTRODUCTION}

Understanding political organization requires the study of hierarchy, which is a governance structure in which each type of actors assumes a different level of responsibility and each actor has more or less political authority over other actors. Diverse traditional theories have studied political hierarchy. Those theories include the traditional view that assumed that humans naturally organized themselves into hierarchies, the distributional approach that defended that hierarchies were explained by inequalities, and the social constructivist approach that understood hierarchies as socially constructed forms of political power embedded in appropriate roles and norms of behaviour (Lake, 2009).

More recently, the new institutional economics has defined a hierarchy as those transactions that are placed under unified ownership (buyer and supplier in the same enterprise) and subject to administrative controls (an authority relation, to include fiat) (Williamson, 1996). This institutional approach is focused on how hierarchy reduces transaction costs and safeguards specific assets in economic exchange (Williamson, 1975, 1985). This new institutional approach highlighted the role of transaction costs in economic exchange and explained how institutions affected the volume of transaction costs and efficiency in economy (Coase, 1984; Williamson, 2000). Specifically, Coase $(1937,1960)$ enabled the justification of the importance of transaction costs in economics and North (1990a) presented institutions as the "rules of the game" in society and showed how institutions have an influence on transaction costs.

This new institutional literature is well known in economics and has contributed to the economic mainstream on institutions and organizations since the end of the $20^{\text {th }}$ Century (Ménard and Shirley, 2005). Nevertheless, the new institutional economics has provided relevant arguments on political transactions and organization too, but these arguments have not been so systematically treated. In this sense, there are different contributions that have indicated the importance of transaction costs in political exchange and market. These contributions are relevant to understand how political institutions affect the volume of political transaction costs and the governance of political organization.

Weingast and Marshall's (1988) seminal paper studied how the industrial organization of the US congress established a "committee system" to facilitate political transactions between congressmen. Later, North (1990b) and Dixit (1996) provided the two main theoretical contributions to the understanding of the role of transaction costs in political life. In this way, "a transaction cost theory of politics is built on the assumptions of costly information, of subjective models on the part of the actors to explain their environment, and of imperfect enforcement of agreements" (North, 1990b, p. 355). Really, transaction costs tend to be systematically higher in political markets than in economic markets, therefore political transactions costs are a key element to understand political governance. Institutions are the rules of the game that determine the level of transactions costs in each po- 
litical transaction, and political governance is a way to reduce transaction costs via different structures of hierarchy and organization.

This paper reviews the role of transaction costs in political exchange as a key element for understanding political organization in society. Second section presents the notions of transaction costs and institutions in economics. Third section introduces the analogy between economics and politics and identifies the key elements that permitted neoclassical economics to treat part of political activity as an exchange. Fourth section analyzes political organization and institutions from the approach of the new institutional economics, and presents the main references of the literature. Fifth section explains why transaction costs are so high in political exchange and incorporates some contributions of this research program. In sixth section, we discuss the boundaries of this approach with other research programs and identify its weaknesses and challenges for the future. The last section concludes on transaction costs and political governance.

\section{TRANSACTION COSTS AND INSTITUTIONS IN THE NEW INSTITUTIONAL ECONOMICS}

The old economic institutionalism (Thorstein Veblen, John Commons, Wesley Mitchell, Clarence Ayres) had studied institutions and organizations from an approach that assumed a holistic method of analysis, a focus on distributive issues and the relevance of coercion, among other elements (Rutherford, 1994). Nevertheless, the new institutional economics emerged from neoclassical economics - which assumed methodological individualism, the emphasis on efficiency and the notion of exchange - but it rejected instrumental rationality by assuming the model of bounded rationality in human decision-making, assumed that the passage of time and history matter in social analysis, and pointed out that economic reality is characterized by positive transaction costs and institutions (North, 1994; Kingston and Caballero, 2009). The main references of the NIE are Ronald Coase, Douglass North, Oliver Williamson and Elinor Ostrom ${ }^{1}$.

In this way, the theoretical framework of the new institutional economics introduced and combined the coasean notion of transaction costs with the northian notion of institutions, such that institutions are a medium for reducing transaction costs and obtaining a greater efficiency in economic performance. On the one hand, Coase (1937) generated a microanalytical approach of organizations which gave rise to "transaction cost economics" (Williamson, 1975, 1985); while on the other

\footnotetext{
${ }^{1}$ Coase, North and Williamson were the founders of the International Society for New Institutional Economics (ISNIE), and they were its three first presidents. They were economists with a large number of contributions during decades and their economic thought evolved towards institutional analysis. Ostrom was a political scientist who liked to be regarded as a political economist, and her thought evolved from a systemic perspective on governance and public policy towards the new institutional economics, and she was involved in the ISNIE too.
} 
hand, Coase (1960) generated a macroanalytical approach that studied the relations between institutions and economic performance, as well as institutional change processes (North, 1990a). The new institutional economics has incorporated both approaches, which are mutually inter-related, that is to say, it has studied institutions and how institutions interact with organizational arrangements within economy (Menard and Shirley, 2005).

Property rights are one's ability to exercise choices over a good. Individuals will carry out transactions, i.e., they will carry out property rights transfers, which will produce positive transaction costs. We can define transactions costs as the resources used to establish, maintain and transfer property rights (Allen, 1991), that is to say, it is the sum of costs required to perform the "transaction function" (North and Wallis, 1994, p. 612). The carrying out of transactions can be construed as a contracting problem, such that transaction costs are those which are derived from the signing ex-ante of a contract and of its ex-post control and compliance (Eggertsson, 1990).

In a world with zero transaction costs, the parties concerned would carry out all such transactions that would result in social efficiency gains (Coase, 1960). However, as against the hypothetical world where negotiation does not cost anything, economic markets are characterized by the presence of positive transaction costs, and therefore no transaction is carried out whenever such costs surpass the expected gains from such transaction. The readjustment of rights will only go ahead whenever the value of exchange from such transactions is greater than the costs implied in transacting it (Coase, 1960).

The level of transaction costs will depend on the characteristic traits of each specific transaction as well as on the nature of the institutional environment in which the transaction is being carried out. In this sense, every society will have its own "rules of the game", which will determine the cost of carrying out transactions (North, 1990a). As North (1990b, p. 359) explained, "in order to lower the costs of exchange, it was necessary to devise a set of institutional arrangements that would allow for exchange over space and time".

Institutions are the rules of the game, that is to say, the humanly devised constraints that structure political, economic and social interaction. Institutions consist of formal rules, informal norms and enforcement mechanisms, and they provide the incentive structure of an economy. While institutions are the rules of the game (customs, norms, behaviour codes, habits...), organizations are collective players of the game (firms, trade-unions, NGOs, lobbies, civil associations...).

In the discovering of organizations-as-players, Coase (1937) established the departing point when he presented the firm as an organizational hierarchy that gives an efficient response to the high transaction costs. Firms can be more efficient than markets because some transactions are better conducted into the firm than in markets. In a world with high transaction costs, hierarchy can safeguard and permit exchanges that otherwise might not occur. Hierarchically organized firms arise to mitigate transaction costs such as the imperfect legal liability laws, incomplete information and the opportunity costs of identifying and bargaining with potential 
buyers or sellers (Lake, 2009). Later, Williamson $(1975,1985)$ showed the relevance of the asymmetrical specific assets in a world of incomplete contracts, because an investment in this type of assets creates a risk of exploitation by opportunistic partners who can appropriate the profits or "quasi-rents" of the investor, therefore safeguards are necessary to guarantee investments (Lake, 2009). Different organizational forms emerge to mitigate transaction costs and the risks of the investment in asymmetrical specific assets.

\section{THE ANALOGY BETWEEN ECONOMICS}

\section{AND POLITICS: EXCHANGE AND MARKETS}

Since the neoclassical economic revolution in the $19^{\text {th }}$ century, mainstream economics has worked as a science of choice where the rational-choice approach to study economic behavior was a key element. At the middle of the $20^{\text {th }}$ century, economists and political scientists started adapting the rational-choice approach to the study of political behavior. The research program of Public Choice was one of the main results of this application of the rational choice theory to politics, and it implied an economic imperialism towards other social sciences, whose risks are evident (mainly, if social scientist does not include the relevance of social, political and institutional factors beyond the rational choice approach).

In a seminal contribution, Downs (1957) developed an economic theory of democracy. He applied the rational logics to the political behavior of governments and voters proposing a positive approach that explains how the governors are led to act by their own selfish motives. Later, the rational choice approach to politics led to Olson (1965) to study the logic of collective action, Riker (1962) to analyze the logic of political coalitions, Buchanan and Tullock (1962) to define the basis of constitutional consensus, and Niskanen (1971) to study the behavior of bureaucracy. In this sense, Buchanan (2003) presented methodological individualism, rational choice and political-as-exchange as the fundamental basis of this research program.

The extension of economic thinking to politics has implied the appearance and development of the concept of political market. Political markets imply the existence of voluntary exchanges of (any type of) political rights. These political markets can be implicit or explicit, and there are very different types of political markets. For example, the diversity and variety of political rights (right to vote, right to legislate, right to govern...) in society imply different categories of political markets. Moreover, the participants in political markets are very diverse (citizens, candidates, legislators, political parties, trade-unions, governments...) and there are a broad set of objects that are exchanged in political markets (votes, political promises, bills, political support...). As a result, political exchanges determine political outputs (public policies, budgets, constitutions...).

In economic markets, exchange can be carried out via barter or via the use of money, which plays the role of medium of exchange and unit of account in econom- 
ics. Neoclassical theory assumes that in economic markets price, determined by demand and supply, represents the exchange value of goods. However, in political markets there is not such an item as money, which would play the role of medium of exchange and unit of account in politics. Therefore political transactions are rather carried out through political barters. Political markets lack of an analogy of the economic price.

Political markets imply the existence of political transactions. This is very clear, for example, in the cases of logrolling (or vote-trading) and pork-barrel in the US politics. Logrolling implies the trading of favors and votes by legislative members to permit passage of bills of interest to each legislator. Pork barrel politics is a particular type of constituency service through which a legislator's geographic constituency benefits from the distribution of public works projects; the desire for reelection prompts a representative to use his influence to initiate local projects (Lancaster, 1986). In both cases, the existence of these political behaviors has implied a clear exchange in those political markets. Nevertheless, the transactional dynamics is not so evident in other political decisions. For example, when the US government has decided to resume political and economic activities with Cuba at the end of 2014, and even to explore the possibility of opening an embassy in La Habana, there are several elements of political exchange behind that decision. The exchange has included the liberation of political prisoners in both countries, and of course, there are other relevant political transactions between both countries (some of them with an economic content and others with a political content).

The analogy between political and economic markets should include other relevant concepts. For example, a firm is a unit of production in the economic neoclassical theory, and in politics there are several political bodies that supply public policies and political outputs in democracy. Citizens may demand diverse types of political goods: there is a political market to exchange votes by policies. As it was shown in previous section, the institutional approach has considered the firm as a governance structure, and in this way, the analogy between economics and politics, allows us to study governance structure in such terms. In transaction costs politics, political organizations - along with institutions - are seen as ways of reducing transaction costs. The resulting organizations may take different forms (hierarchical, hybrid...) and we will discuss some examples in next sections. The analogy implies that in politics political organizations are the analogous element of the firm-as-governance structure.

In any case, this analogy between economics and politics should specify its boundaries because "arguments drawn from economics must be sensitive to the quite different nature of the political world" and "politics differs from economics in many ways" (Pierson, 2000). For example, the outputs of political markets establish the distribution of the property rights that are exchanged in economic markets, therefore political rights are in a different social level of that of the economic property rights (Williamson, 2000). The central role of collective action, coercion and shared mental models in politics implies several differences with the economic performance. Many of these differences between politics and economics 
will imply the high intensity of transaction costs in politics, as we will show in the following sections that will explain the specificities of politics in comparison with economics. In any case, the analogy has been useful to study diverse political phenomena and exchanges.

\section{INSTITUTIONAL ANALYSIS: POLITICAL RULES AND POLITICAL ORGANIZATIONS}

In the pre-coasean neoclassical world where transaction costs are zero, political activity would correspond to a simple assignment of rights that would permit efficiency through transfer of rights from owners who value them less to those that value them more (no "Pareto improvement" would stay unexecuted) (North, $1990 \mathrm{~b})$. This situation allows us to derive a macro version of Coase's theorem according to which economic growth is not affected by the type of government of a country as long as transaction costs are zero (Eggertsson, 1990). But we can go a step further in the reasoning process and conclude that in such an ideal world, the political process would not matter, since an efficient plan would always be achieved (Dixit, 1996).

But if the presence of transaction costs decisively affects economic exchange, the relevance of transaction costs is even greater for the functioning of political markets. The peculiar nature and intensity of these costs in political transactions convert them into an irreplaceable concept when we try to get a better understanding of politics. This is so not only for political transactions carried out between citizens and politicians, which both North $(1990 \mathrm{~b})$ and Dixit $(1996,1998)$ emphasize, but also for those in which all participants are politicians, as dealt with by Weingast and Marshall (1988), Epstein and O'Halloran (1999) and Spiller and Tommasi (2007).

The transactional approach considers political transaction as the unit of political analysis and explains the evolution of political relationships as transactions and contracts. It highlights the relevance of institutions and organization in political markets characterized by incomplete political rights, imperfect enforcement of agreements, bounded rationality, imperfect information, subjective mental models on the part of the actors and high transaction costs. The institutional structure of polity acts as a set of rules that determines the individual incentives and the volume of transaction costs, and therefore biases political output.

The research program of transaction cost politics has sustained that governance structures are political institutions and organizations. Both structures matter and can be analyzed, and one of their function is economizing transaction costs. This research program understands political activity as a dynamic process in evolution, which is incomplete and imperfect and which takes place in "real time", in history (Dixit, 1996, 1998). There are several seminal contributions of the transaction cost political analysis, and Table 1, at the end of this paper, presents the main references of the literature. 
If Weingast and Marshall (1988) and North (1989) are the two main pioneering papers of this research program, North (1990b) and Dixit (1996) are the two fundamental contributions and provided the theoretical bases for the program. Epstein and O'Halloran (1999) and Lake (2009) applied the transactional perspective from a political science point of view, while Williamson (1999) extended his transaction cost economics approach towards the study of bureaucracies. Spiller and Tommasi $(2003,2007)$ studied the institutional foundations of public policy in Argentina from a transaction cost approach and Dixit (2003) provided some lessons for less developed countries.

If we distinguish four levels of social analysis, the top level would be the social embeddedness level (informal norms, customs, traditions), the second level would be the institutional environment (formal rules of the game: polity, judiciary, bureaucracy), the third level would be the institutions of governance (contracting, transacting, organizations) and the fourth level would include the resource allocation and employment (prices and quantities) (Williamson, 2000). The second and the third level would try to get the institutional environment and the governance structures right respectively. Both goals (i.e., right institutional environment, right governance structures) imply an order economizing, and political rules and organizations are integrated in those orders.

Firstly, political rules are the way to get the institutional environment right. Constitution, political and civil rights, check and balance, rule of law and electoral system, among others, are the key elements to establish the institutional framework of each society. North and Weingast (1989) explained how political change in England opened a better institutional environment in $17^{\text {th }}$ century. Recently, Acemoglu and Robinson (2011) defended the relevance of political institutions over other issues to explain economic development.

Secondly, political organization is a way to get the governance structures right. The new institutional economics understood firm as an organization, but the theory of the firm-as-hierarchy elaborated by Coase and Williamson has been broadened to include other social and political organizations: while economic transactions are internalized in the firm to minimize transaction costs, political governance is a way to minimize transaction costs in political life (Lake, 2009). In this way, studying why transaction costs are so high in political exchange will help us to understand political governance and, specifically, the role of political institutions and organizations.

\section{TRANSACTION COSTS IN POLITICAL EXCHANGE:}

\section{A DETAILED CATALOGUE}

North (1990b, p. 362) assumes that "political markets are far more prone to inefficiency" and concludes that transaction costs are even higher in politics than in economics, therefore the design of an efficient institutional and organizational structure becomes more complex in the political world. Besides considering the 
contract as an analysis unit, the research program on political transaction costs also studies the enforcement mechanism of contracts, compares the different governance structures, takes into account path dependence and adopts the bounded rationality supposition (Epstein and O'Halloran, 1999, Dixit, 1996). Moreover, this research program gives a central role to the notion of credible commitment, which justifies the importance of reputational capital and the organizational formulae of the State (North, 1993; North and Weingast, 1989). Furthermore, in recent times, we are witnessing the progressive vision of public policies as a result of a series of inter-temporal political transactions.

A very relevant consideration is essential for the understanding of transaction costs in political exchange: while economic competition takes place on property rights that are normally safe, political competition includes the fight for authority and this means change of rights. Therefore, politics revolves around a set of less safe rules, thereby hampering the definition of an order that favours exchange (Furubotn and Richter, 1998). Moreover, coercion is present in political fight for authority (Nye, 1997; Moe, 2005).

Transaction costs tend to be systematically higher in political markets than in economic ones due to several reasons (North, 1990b; Dixit, 1996; Caballero and Arias, 2003). The reasons that explain the high level of transaction costs in political exchange and organization are the following: (a) In political contracts, the parties to the contract cannot be perfectly identified in many cases and this happens especially when one of the parties is a multiple subject; furthermore, many political contracts are neither explicit nor formal and rest on verbal and even tacit agreements. (b) Even if they were explicit, political contracts clearly respond to an incomplete contract prototype, containing vague and interpretable terms. This implies that the ex-post power relations matters exceedingly: the possession of the residual rights of control is key when, for example, an uncontracted eventuality occurs. Moreover, ex-post control rights may exert strong influence over ex-ante contractual arrangements (Epstein and O'Halloran, 1999). (c) Property rights are subject to strong constraints within political interactions: they are not safe nor do agents possess them in an unlimited manner. (d) The world of politics is opaque, unclear and it is difficult to observe and measure the different factors of political performance, for example the measure of objects of political transaction is really complex and partially subjective (Pierson, 2000). In this sense, political markets lack a measurement formula like the price system in economic markets. (e) Political action promises are a fundamental exchange unit in political contracts but such promises are typically not subject to a compliance mechanism (there is not an effective "third party enforcement" in politics). (f) Political transactions affect many agents due to the wide presence of overflow effects that enable interpretation of interaction among political agents along terms of a "common agency" relationship with multiple principals (Dixit, 1996). Furthermore, the structure of agency-relation amongst political actors tends to be especially complex: an example can be the vertical agency-relation that is configured by the chain "electorate-parliament-governmentbureaucracy", and yet another example can be the governance of territorial distri- 
bution of power. (g) Situations of asymmetric information are particularly relevant in political transactions and furthermore, the subjective models of the actors increase the amount of transaction costs even more in political markets (therefore different ideologies affect political exchange). (h) The problem of collective action characterizes a wide range of political transactions. The collective nature of politics makes the consequences of my action depend highly on actions of others, such that the relationship between effort and effect becomes quite unclear and informational problems are augmented (Pierson, 2000). (i) High transaction costs issues gravitate to polity from the economy (North, 1990b). (j) Political institutions tend to establish a bias towards status quo which hampers change and adaptation to new situations, and there exists an institutional density that incorporates constraints based on authority. In this sense, the structure of power can hamper exchange (Pierson, 2000), and the carrying out of institutional adjustments to reduce transaction costs. $(\mathrm{k})$ The choice and evolution forces in political markets are slower and weaker than in economic markets, leading to a lower efficiency and a less intense choice of organisations (Dixit, 1996). That is to say, the corrective and learning mechanisms are less effective in political scenarios characterised by a path with increasing returns (Pierson, 2000). (1) To the above, we must add the difficulties of defining institutions that achieve a high influence of incentives in the political process (Dixit, 1996). (m) The short-term horizon of political actors, who are interested in the electoral logic, contrasts with the nature of those political decisions whose implications only play out in the long run. While the economic marketplace possesses some strong mechanisms for lengthening time horizons (such as property rights and capital markets), there are no analogous mechanisms that are equally effective in politics (Pierson, 2000). (n) Political transaction costs sometimes are increased intentionally; political actors manipulate them strategically to achieve personal objectives. In this way, politically relevant transaction costs are also to a great extent endogenously determined through self-interested use of government mechanisms. There are several ways of political transaction-cost manipulation (using informational costs, costs of negotiation, agreement or enforcement), and there are some specific conditions under which officeholders are predicted to act via manipulation of political transaction costs (Twight, 1994). (o) Since public policies are not spot transactions, cooperation requires striking and enforcing intertemporal political agreements, that is, agreements that can be enforced over time. The intertemporal nature of political exchanges increases transaction costs (Spiller and Tommasi, 2007). This is the case of those contracts whose bills are not simultaneously considered for a vote, and the case of those with non-contemporaneous benefit flows (Weingast and Marshall, 1988). (p) Public policies with more complex transaction characteristics will require more institutional safeguards to make them effective over time (Spiller and Tommasi, 2007).

The high transaction costs of political markets imply that it is fundamental to study institutions and the governance formula that structures political processes in each society. The research program on transaction cost politics has studied different political issues and case studies to understand how political institutions and orga- 
nizations work in practice. Table 2, at the end of this paper, shows some contributions that are relevant to understand transaction cost in politics, although they come from diverse authors and perspectives.

In order to cope with these transaction costs, actors may recur to the design of governance mechanisms, i.e., institutions and organizations. These formulae may take different forms depending on a number of factors, such as the nature of the operation, the actors, the transaction costs, the institutional environment, etc. This is why empirical research provides excellent and detailed examples to understand the relationship among transaction costs, the institutional and organizational structures to economize them and the capacity to obtain efficient outcomes from the interaction of the actors involved. In the following paragraphs, we review some of the mechanisms that arise to cope with transaction costs contained in the theoretical and empirical literature.

Several works have been focused on the governance structures of legislative bodies and their success to cope with transaction costs. Weingast and Marshall's (1988) seminal paper studied how the legislative institutions in the US Congress fit to the logic of the industrial organization and show how "committee system" facilitates political transactions among congressmen. Similarly, Spiller and Tommasi (2003, 2007) applied the TCP approach to the case of Argentinian political institutions in the formulation of public policy. They argue that the institutional structure of Argentina reduces the capacity to undertake efficient intertemporal political exchanges. More recently, Caballero (2011) continues their approach and makes a comparative analysis of Congress governance in the US, Argentina and Spain.

The specific transaction costs arising from the lack of capacity to make credible commitments, the information asymmetry and other agency problems were also addressed in a wide range of subsequent studies. To solve the problems of credible commitments, there exist well-known options like locking-in actions (Dixit 1996, p. 65) or delegation (Epstein and O'Halloran 1999). In practice, they take the form of, for instance, binding agreements - e.g., the European Stability and Growth Pact - or delegation in independent nonmajoritarian agencies (Majone $2001)$ - e.g., the delegation of monetary policy to independent Central Banks. In this line, separation of power have been pointed as an institutional form that at different levels helps to mitigate transaction costs and improve policy outcomes, as argued by Laffont and Martimort (1998) and Beggreen and Karlson (2003). Caballero et al. (2006) analyzed the problem of credibility in the commitment of the Stability and Growth pact. Compliance with this contract could be ensured by a "third-party enforcement" or an interest in reputational capital, but some countries failed to comply with the ruling and managed to avoid the application of sanctions.

Organizational structures that secure high degree of transparency are of fundamental importance to deal with the transaction costs arising from imperfect information and information asymmetries. Baccini (2014) shows how the quality of institutions raises the quantity and the quality of information available to potential member states during the bargaining phase of a trade agreement. This inflow of information reduces the negotiation period of the agreement, thereby dampening 
the transaction costs associated with it. Jones and Hudson (1998) argue that political parties play a fundamental role in coping transaction costs derived from incomplete information. Political parties reduce voters' information costs. Additionally, they argued in a subsequent article (Jones and Hudson, 2001) that if voters reduce transaction costs by relying on party signal, politicians have an incentive to maintain party reputation, which is pointed as a main factor to prevent opportunism.

Therefore, transaction costs affect the form of the governance structures. Weber (1997) relies on the transaction cost politics to explain the form that hierarchies may take in international relations. She applies her proposal to the plans formulated in the 1950s for the creation of the European Defense Community. Nations are willing to renounce to part of their autonomy to create hierarchic governance structures that raise the cost of opportunism. The degree of transaction costs derived from the possibility of opportunism affects the degree of institutional bindingness that nations would prefer. Other studies have shown the effect of transaction costs in the concrete design of budgeting institutions (Patasksnik, 1996), the public sector organizational arrangements (Gallego-Calderón, 1998), the regulatory institutions (Estache and Martimort, 1999), the form of autonomization of government organizations in the Netherlands (Ter Bogt, 2003), and the consolidation of local authorities in Norwegian local governments (Sorensen, 2006).

Other works focused on the effect of transaction costs in the survival and functioning of given institutions or the designing process of future institutions. Hindmoor (1998) applied the transactional approach to the negotiations between the British Medical Association and the Ministry of Health prior to the creation of the National Health Service. He explained how, in absence of proper governance structures, policy communities and trust were fundamental to reduce transaction costs that would otherwise threaten the exchange of resources between government and pressure groups.

In recent years, new contributions have evidenced the utility of transactional analysis to study diverse issues of political performance. For example, Gilligan (2014) shows the possibilities of transactional analysis to understand international political institutions, and Krutilla and Alexeev (2014) deal with the role of transaction costs in environmental policy.

\section{BOUNDARIES, WEAKNESSES AND CHALLENGES}

If the previous sections allowed us for an approach to the study of transaction costs in politics, this section shows the complexity, weaknesses and challenges of the research program of transaction cost politics. First, regarding the boundaries, this section shows the frontiers of transaction cost politics inside the new institutionalism and its relationships with other new institutional programs, and then the relationship between new and original institutional economics will be analyzed. Second, we are going to point some weaknesses of transaction cost politics and a set of challenges of the program will be identified. 
First, new institutionalism has emerged in economics, politics and sociology in recent time, and it has been distinguished a variety of approaches inside the new institutionalism in social sciences (Peters, 1999). Transaction costs politics has constituted a new transactional institutionalism to study political transactions and institutions. Regarding its frontiers inside the new institutionalism, transaction costs politics is not related to other new institutional approaches such as normative institutionalism, empirical institutionalism, sociological institutionalism, interestrepresentation institutionalism and international institutionalism, but it was founded on the contributions of the rational-choice institutionalism and the new institutional economics, therefore receiving some non-direct influence from the historical institutionalism. Transaction cost politics coincides with the rational-choice institutionalism because both are interested in political markets and institutions, both understand political institutions as cooperative structures and assume a model of rationality for political behavior. However, transaction cost politics is different from rational-choice institutionalism because transaction cost politics assumes three characteristic foundations of NIE (bounded rationality, a transactional approach, the passage of time matters) and these characteristics had not been assumed by rational-choice institutionalism. In this sense, transaction cost politics constitutes an extension of the new institutional economics towards an analysis of politics from a madisonian perspective (Caballero and Arias, 2013).

In any case, transaction cost politics has emerged as a truly new institutional approach. Regarding the frontiers of this approach, some issues on the relationship between the original and new institutional economics should be noticed.

The original economic institutionalism had developed from its beginnings a deep critique of the economic orthodoxy, from the models of human behavior to the very understanding of economic operation at aggregate level. At the beginning of the nineties, Dugger (1990) argued that the new institutionalism should not be considered institutionalist due to several reasons, and he pointed out that institutionalism should emphasize the role of power and predatory activities in the economy, institutional analysis should take an evolutionary approach to the study of social provisioning and institutionalism should conceive economies as evolving wholes. He considered that new institutionalism did not adequately assume these issues. Nevertheless the contributions of the new institutional economics since the nineties have assumed a truly institutional perspective that has surpassed the requirements of Dugger (1990). In this way, Groenewegen et al. (1995), Hodgson (1998), Rutherford (2001), Kingston and Caballero (2009) and Caballero and Soto (2015), among others, has explained the institutional content of the new institutional economics and the interactions between original and new institutionalism in economics.

For example, in recent times the new institutional economics has surpassed the limits of methodological institutionalism, incorporated the relevance of power and focused on distributive effects. Thus, the new institutionalism developed the notion of institutional individualism (Toboso, 2001); the role of power and coercion in economics and politics has been treated during the recent decades (North, 1990a; 
Knight, 1992; Nye, 1997; Acemoglu and Robinson, 2008; North et al., 2009) and the distributive issues have been studied in diverse contributions (Toboso, 2011). Moreover, new institutionalists recognized the effect of the passage of time on institutions and were gradually approaching to an evolutionary perspective of the path of history (Caballero and Soto-Oñate, 2015).

Specifically, transaction cost politics appears among the developments of the new institutionalists that allow an approach between the new and the original institutionalism. This is evident regarding, firstly, the evolutionary approach, and secondly, the non-substantive rational perspective of transaction cost politics. First, according to Dixit (1996), transaction cost politics understands political activity as a dynamic process in evolution, which is incomplete and imperfect and which takes place in "real time", in history, as explained in the previous sections. Second, according to North (1990b), the subjective models of the actors are a key element to transaction cost politics and "ideologies underline the subjective model that individual models to explain the world around them".

In any case, at the present moment the new institutionalism includes an incomplete research agenda to understand culture, ideology and other shared informal traits that are fundamental in human behavior. In a comparison between old and new institutionalism, Dequech (2002) focused on a central feature which represents an essential difference between both institutionalisms: the foundations of individual behavior. While the new institutionalism had started from the notion of complete and consistent individuals with an independent nature from the environment in which it operates, the original institutionalism had conceived the individual as "a product of culture" (Mayhew, 1989). During its beginnings, the new institutionalism had tended to share the neoclassical notion of rational, utility-maximizer behavior. However, the original institutionalists, who see individual behavior as based on habits -mainly inherited from the community -, believe that adopting the methodological individualism leads to neglect the most important part of economic and political behavior. In recent contributions the new institutionalism has abandoned the strict methodological individualism and gradually recognized the importance of culture and included in its formulations a set of beliefs, values and attitudes that help to deal with central phenomena, such as path-dependence or opportunism (North, 1990, 2005; Denzau and North, 1994; Greif, 2006; North et al. 2009). In any case, although the new institutionalism has recognized the importance of cultural and ideological phenomena and their effect on individuals' construction of reality, it was far from having developed an appropriate theoretical apparatus with which to face these cultural issues. This is a weak point of the new institutionalism, and specifically of transaction cost politics, because culture and ideology are key factors to understand political performance and transactions. Among the most significant challenges for the future of new institutionalism is the development of a proper framework that incorporates culture and ideology.

Furthermore, making operative how to deal with coercion in political transactions is other relevant challenge for the study of transaction cost in politics. The degree of voluntarism and freedom can be different in diverse political transactions, 
and although Nye (1997) already presented this issue, new advances are necessary to understand transactions and coercion in democracy and dictatorship. In fact, Moe (2005) pointed out that political institutions may be structures of cooperation, but they may also be structures of power, and he demanded a more balanced theory that incorporates power and cooperation.

As posed in the fifth section, governance structures may take a wide range of forms with accordance of an endless list of factors. Therefore, transaction cost politics has to rely necessarily on a broad body of empirical research (Caballero and Arias, 2013). A larger effort must be done in this sense in order to provide a set of governance solutions to the enormous variety of transactional problems that societies have to face.

Furthermore, although there has been an approach among institutional approaches (Shepsle, 2006; Caballero and Soto-Oñate, 2015), still a more intense dialog between them and with other social sciences should be hold. A long way to walk remains in the understanding of core phenomena for social sciences, such as organizational structure, institutional change or individual behavior, and it seems impossible to undertake without a multidisciplinary approach.

\section{CONCLUSION}

The new institutionalism has strongly emerged in social sciences in recent years, and the transactional approach has constituted a research program on political organization studies. This paper has introduced the main contributions on transaction costs in political governance, reviewed the main arguments and provided a detailed catalogue on political transaction costs research that is consistent with a new institutional approach.

Institutions provide the rules of the political game, and they determine the incentive structure of political agents, and therefore determine a high level of public policy outputs. The application of the transactional approach to the political field leads us to consider political interaction as a set of (implicit or explicit) contractual relations, and, in this sense, public policies are the outcome of transactions among policy-makers. Moreover, political transactions include the transactions between politicians and citizens too (for example, the trading of votes and contributions for promised policies). Therefore, political transactions are a key element in political life because they include transactions carried out between citizens and politicians but also those in which all participants are politicians. As pointed by the transaction cost politics, the most important issue is that all these types of transactions imply high transaction costs, and they may be coped by governance structures.

Institutions resolve a first order economizing via the establishment of an institutional environment that consists of political rules, property rights, polity, State, judiciary, bureaucracy... That institutional framework should try to reduce transaction costs and propel economic and political exchange. Once the institutional environment is established, individuals organize political governance structures to 
achieve their goals in society (political parties, committees, trade-unions, lobbies...). It implies a second-order economizing (i. e., get the governance structures right) and determines the type of political organization and hierarchy existing in society (Williamson, 2000). Moreover, organizational structures of governance will be quite relevant when explaining the relations between institutions and outcomes.

Political governance is related to institutions and organizations that allow political exchange and may reduce transaction costs. Reducing political transaction costs is a way to improve welfare in society. Studying the right institutional and organizational design is crucial to improve welfare because transaction costs are higher in politics than in economics and high transaction costs prevent political exchange. Relevant advances on institutional design have been provided by this research program in recent years. These advances are collected in the contributions of Tables 1 and 2, and include the design of legislatures and parties, the structure of the State and the relationships among states (Lake, 2009). This survey had to be necessarily selective given the volume of the arguments of the related literature, but Tables 1 and 2 are the useful complements to those who are interested in a higher level of specialization in the transaction costs politics literature. The tables introduce the main literature.

Here we have presented some examples about how high transaction costs in politics have been alleviated by designing governance mechanisms. However, the range of possibilities and the diversity of situations give rise to a wide diversity of organizational devises. Indeed, governance solutions to a given similar political situation are likely to vary across societies. As Dixit puts it, "every country has its peculiarities of history, geography, culture, population, language and many other characteristics that determine the operation and evolution of its politics and institutions" (1996, p. 107). Therefore these factors will also affect both the nature of the transaction and ability and possibilities to cope with them by designing governance structures.

Transaction Cost Politics has shown the relevance of transaction costs in political governance, and contemporaneous political economy has incorporated its lessons. However, as we have seen in previous section, still some weaknesses remain to be solved and they must be set as challenges for a future agenda on transaction costs and politics.

\section{REFERENCES}

Acemoglu, D. (2003), "Why not a political Coase theorem? Social conflict, commitment and politics", Journal of Comparative Economics, 31 (4), pp. 620-652.

Acemoglu, D. and J. Robinson (2008), "Persistence of power, elites, and institutions," American Economic Review, 98(1): 267-293.

Acemoglu, D. and J. Robinson (2011), Why Nations Fail. New York: Crown Publishers.

Allen, D.W. (1991), "What are transaction costs?" Research in Law and Economics, N. 14, pp. 1-18.

Baccini, L. (2014): “Cheap talk: Transaction costs, quality of institutions, and trade agreements”, European Journal of International Relations, Vol 20 (1), pp. 80-117. 
Berggren, N. and N. Karlson (2003), “Constitutionalism, division of power and transaction costs”, Public Choice, V. 117, N. 1-2, pp. 99-124.

Buchanan, J.M. (2003) "Public Choice: The origins and development of a research program". Center for the Study of Public Choice, George Mason University.

Buchanan, J. M. and G. Tullock (1962): The Calculus of Consent. Logical Foundations of Constitutional Democracy. Ann Arbor: University of Michigan Press.

Caballero, G. (2011), "Institutional foundations, committee system and amateur legislators in the governance of the Spanish congress: An institutional comparative perspective (USA, Argentina, Spain)", pp. 157-184, in Schofield, N. and G. Caballero (eds) (2011): Political Economy of Institutions, Democracy and Voting. New York: Springer.

Caballero, G. and X. C. Arias (2003), "Una reorientación teórica de la economía política: el análisis político de costes de transacción”, Revista Española de Ciencia Política, N. 8, pp. 131-164.

Caballero, G. y X. C. Arias (2013) "Transaction cost politics in the map of the new institutionalism", pp. 3-31, en Schofield, N., Caballero G. y D. Kselman (eds): Advances in Political Economy: Institutions, Modeling and Empirical Analysis. New York: Springer.

Caballero, A., Caballero, G. and A. Losada (2006) "Credibility, rules and power in the European union institutions: a transactional analysis of the stability and growth pact", Brazilian Journal of Political Economy, Vol. 26, N. 3 (103), pp.445-458.

Caballero, G. and D. Soto-Oñate (2015) "The diversity and rapprochement of theories of institutional change: Original institutionalism and new institutional economics", Journal of Economic Issues, 49 (4), p. 947-977.

Coase, R. H. (1937), “The nature of the firm", Economica, N. 4, pp. 386-405.

Coase, R. H. (1960), "The problem of social cost", Journal of Law and Economics, V. 3, N. 1, pp. 1-44.

Coase, R. H. (1984), “The New Institutional Economics”, Journal of Theoretical and Institutional Economics, Vol. 140, N. 1, pp. 229-231.

Dequech, D. (2002), "The demarcation between the "Old" and the "New" Institutional Economics: Recent complications," Journal of Economic Issues, 36(2): 565-571.

Dixit, A. (1996), The Making of Economic Policy: A Transaction-Cost Politics Perspective. Cambridge: The MIT Press.

Dixit, A. K. (1998), “Transaction cost politics and economic policy: a framework and a case study”, in M. Baldassarri (ed) (1998): Institutions and Economic Organization in the Advanced Economies. New York: St. Martin's Press.

Dixit, A. K. (2003), “Some lessons from transaction-cost politics for less-developed countries”, Economics and Politics, Vol. 15, N. 2, pp. 107-133.

Downs, A. (1957) An Economic Theory of Democracy. Boston: Addison Wesley.

Dugger, W. M. (1990), “The new institutionalism: new but not institutionalist”, Journal of Economic Issues, 24(2): 423-431.

Eggertsson, T. (1990), Economic Behaviour and Institutions. Cambridge: Cambridge University Press.

Epstein, D. and S. O'Halloran (1999), Delegating Powers. A Transaction Cost Politics Approach to Policy Making Under Separate Powers. Cambridge: Cambridge University Press.

Estache, A. and D. Martimort (1999), "Politics, transaction costs and the design of regulatory institutions”, World Bank Policy Research.

Gallego-Calderón, R. (1999), "Institutional design in the public sector: the role of political transaction costs”, ECPR Joint Session, Mannheim, 26-31 March.

Gilligan, M. (2014), "The transaction costs approach to international institutions", in H. V. Milner \& A. Moravcsik, eds. (2014): Power, Interdependence, and Nonstate Actors in World Politics, Princeton: Princeton University Press.

Greif, A. (2006), Institutions and the Path to the Modern Economy. Cambridge: Cambridge University Press.

Groenewegen, J., F. Kerstholt and A. Nagelkerke (1995), “On integrating new and old institutionalism: Douglass C. North building bridges”, Journal of Economic Issues, 29(2): 467-476. 
Henisz, W. J. and B. A. Zelner (2004), "Explicating political hazards and safeguards: a transaction cost politics approach", Industrial and Corporate Change, 13, 6, pp. 901-915.

Hindmoor, A. (1998), "The importance of being trusted: Transaction costs and policy network theory", Public Administration, Vol. 76, pp. 25-43.

Hodgson, G. M. (1998), “The approach of institutional economics”, Journal of Economic Literature, 36: 166-192.

Jones, P. and J. Hudson (1998), "The role of political parties: An analysis based on transactions costs", Public Choice, 94, pp. 175-189.

Jones, P. and J. Hudson (2001), "Political parties, political integrity and public policy: a transactions costs approach", Political Studies, V. 49, pp. 70-88.

Kingston, C., and G. Caballero (2009), "Comparing theories of institutional change", Journal of Institutional Economics, Vol. 5 (2), pp. 151-180.

Knight, J. (1992), Institutions and Social Conflict. Cambridge: Cambridge University Press.

Krutilla and Alexeev (2014), "The political transaction costs and uncertainties of establishing environmental rights”, Ecological Economics, 107, pp. 299-309.

Laffont, J.J. and D. Martimort (1998), “Transaction costs, institutional design and the separation of powers”, European Economic Review, 42, pp. 673-684.

Lake, D. A. (2009), "Hobbesian hierarchy: the political economy of political organization", Annual Review of Political Science, 12, pp. 263-283.

Lancaster, T. A. (1986): “Electoral structures and pork barrel politics”, International Political Science Review, 7(1), pp. 67-81.

Majone, G. (2001), "Nonmajoritarian institutions and the limits of democratic governance: a political transaction-cost approach", Journal of Institutional and Theoretical Economics, N. 157, pp. $57-$ 78.

Mayhew, A. (1989), "Contrasting origins of the two institutionalisms: the social science context", Review of Political Economy, 1(3): 319-333.

Menard, C. and M. Shirley (2005), Handbook of New Institutional Economics. New York: Springer.

Moe, T. M. (1990), "Political institutions: the neglected side of the story", Journal of Law, Economics and Organization, N. 6, pp. 213-253.

Moe, T. M. (2005), "Power and political institutions", Perspectives on Politics, Vol. 3, N. 2, pp. 215 233.

Murshed, S. M. (2001), “Transaction cost politics, institutions for commitment and rent-seeking”, Discussion Paper N. 125. WIDER. United Nations University.

Niskanen, W. A. (1971): Bureaucracy and Representative Government. Chicago: Aldine.

North, D. C. (1989), "A transaction cost approach to the historical development of polities and economies", Journal of Institutional and Theoretical Economics, N. 145, pp. 661-668.

North, D. C. (1990a), Institutions, Institutional Change and Economic Performance. Cambridge: Cambridge University Press.

North, D. C. (1990b), "A transaction cost theory of politics". Journal of Theoretical Politics, Vol. 2, N. 4, pp. 355-367.

North, D. C. (1993), “Institutions and credible commitment”, Journal of Institutional and Theoretical Economics, Vol. 149, N. 1, pp.11-23.

North, D. C. (1994), "Economic performance through time", The American Economic Review, Vol. 84, N. 3, pp. 359-368.

North, D. C. (2005), Understanding the Process of Economic Change. Princeton: Princeton University Press.

North, D. C. and B. R. Weingast (1989), "Constitutions and commitment: the evolution of institutions governing public choice in seventeenth-century England”, The Journal of Economic History, Vol. 49, N. 4, pp. 803-832.

North, D. C. and Wallis, J. J. (1994), “Integrating Institutional change and technical change in economic history. A transaction cost approach", Journal of Institutional and Theoretical Economics, Vol. 150, N. 4, pp. 609-624. 
North, D. C., J. J. Wallis and B. R. Weingast (2009), Violence and Social Orders. New York: Cambridge University Press.

Nye, J. V. (1997), “Thinking about the State: property rights, trade, and changing contractual arrangements in a world with coercion", pp. 121-144, en Drobak, J. N. y J. Nye (eds) (1997): The Frontiers of the New Institutional Economics. San Diego: Academic Press.

Olson, M. (1965): The Logic of Collective Action. Cambridge: Harvard University Press.

Patashnik, E. (1996), "The contractual natural of budgeting: A transaction cost perspective on the design of budgeting institutions”, Policy Sciences, 29, pp. 189-212.

Peters, G. (1999), Institutional Theory in Political Science: The New Institutionalism. London: Routledge.

Pierson, P. (2000), "Path dependence, increasing returns and the study of politics", American Political Science Review, N. 94, pp. 251-267.

Riker, W. (1962), The Theory of Political Coalitions. New Haven: Yale University Press.

Ruiter, D. W. P. (2005), "Is transaction cost economics applicable to public governance?" European Journal of Law and Economics, 20, pp. 287-303.

Rutherford, M. (1994), Institutions in Economics. Cambridge: Cambridge University Press.

Rutherford, M. (2001), "Institutional economics: then and now," Journal of Economic Perspectives, 15(3): 173-194.

Scartascini, C. (2007), “The institutional determinants of political transactions”, Working Paper N. 580, Inter-American Development Bank. Washington DC.

Shepsle, K. A. (2006), "Rational choice institutionalism", in Binder S., Rhodes R. and B. Rockman (eds): Oxford Handbook of Political Institutions. London: Oxford University Press.

Sorensen, R. J. (2006), "Local government consolidations: The impact of political transaction costs", Public Choice, 127, pp. 75-95.

Spiller, P. T. and M. Tommasi (2003), "The institutional foundations of public policy: A transactions approach with applications to Argentina", Journal of Law, Economics and Organizations, V.19, N. 2, pp. 281-306.

Spiller, P. T. and M. Tommasi (2007), The Institutional Foundations of Public policy in Argentina. A Transaction Cost Approach. Cambridge: Cambridge University Press.

Ter Bogt, H. (2003), “A transaction cost approach to the autonomization of government organizations: a political transaction cost framework confronted with six cases of autonomization in the Netherlands", European Journal of Law and Economics, 16, pp. 149-186.

Toboso, F. (2001), "Institutional individualism and institutional change: the search for a middle way mode explanation", Cambridge Journal of Economics, 25: 765-783.

Toboso, F. (2011), "Institutional arrangements matter for both efficiency and distribution: Contributions and challenges of the New institutional Economics", in Political Economy of Institutions, Democracy and Voting, edited by N. Schofield and G. Caballero. New York: Springer.

Twight, C. (1994), "Political transaction-cost manipulation. An integrating theory", Journal of Theoretical Politics, Vol. 6, N. 2, pp. 189-216.

Weber, K. (1997), "Hierarchy amidst anarchy: a transaction costs approach to international security cooperation”, International Studies Quaterly, 41, pp. 321-340.

Weingast, B. R. and W. J. Marshall (1988), "The industrial organization of congress; or, why legislatures, like firms, are not organized as markets”, Journal of Political Economy, Vol. 96, 1, pp. 132 163.

Williamson, O. E. (1975), Markets and Hierarchies. New York: The Free Press.

Williamson, O. E. (1985), The Economics Institutions of Capitalism: Firms, Markets, Relational Contracting. New York: The Free Press.

Williamson, O. E. (1999), "Public and private bureaucracies: a transaction cost economics perspective", Journal of Law, Economics and Organizations, V. 15, N. 1, pp. 306-342.

Williamson, O. E. (2000), “The new institutional economics: taking stock, looking ahead”, Journal of Economic Literature, Vol.38, pp. 595-613.

Wood, B. D. and J. Bohte (2004), "Political transaction costs and the politics of administrative design", The Journal of Politics, V. 66, N. 1, pp. 176-202. 
Table 1: Transaction Costs in Political Governance: the Main References

Note: This Table incorporates the main references that established the foundations of the research program of transaction cost politics.

\begin{tabular}{|c|c|c|}
\hline Author (Year) & Title & Topic \\
\hline $\begin{array}{l}\text { Weingast } \\
\text { and Marshall } \\
\text { (1988) }\end{array}$ & $\begin{array}{l}\text { The Industrial Organization } \\
\text { of Congress; or, Why } \\
\text { Legislatures, Like Firms, Are } \\
\text { Not Organized as Markets }\end{array}$ & $\begin{array}{l}\text { This paper studies the organization of American Congress, showing } \\
\text { how the legislative institutions enforce bargains among legislators } \\
\text { and how specific forms of non-market exchange (in particular a } \\
\text { committee system) prove superior to markets exchange. }\end{array}$ \\
\hline North (1989) & $\begin{array}{l}\text { A Transaction Cost Approach } \\
\text { to the Historical Development } \\
\text { of Polities and Economies }\end{array}$ & $\begin{array}{l}\text { This paper extends the transaction cost approach to political } \\
\text { exchange and explores the interaction of political and economic } \\
\text { institutions in the development of polities and economies. }\end{array}$ \\
\hline North (1990b) & $\begin{array}{l}\text { A Transaction Cost Theory } \\
\text { of Politics }\end{array}$ & $\begin{array}{l}\text { This paper plays a key role in the emergence of TCP as a program } \\
\text { of political analysis, via the application of North's institutional the- } \\
\text { ory to political markets. It characterizes the costs of transacting } \\
\text { in political markets, studies the role of ideology in shaping politi- } \\
\text { cal choices and explores the performance of polities over time. }\end{array}$ \\
\hline Dixit (1996) & $\begin{array}{l}\text { The making of economic } \\
\text { policy: A Transaction Cost } \\
\text { Politics Perspective }\end{array}$ & $\begin{array}{l}\text { When this book approaches the economic policymaking as a poli- } \\
\text { tical process in real time, it establishes the differences of TCP with } \\
\text { "the normative approach to policy analysis" and "the positive view } \\
\text { of political economy". The book is a key contribution for the con- } \\
\text { solidation of TCP. It analyses the transaction costs in politics and } \\
\text { focuses on the feature of "common agency" of policy-making. }\end{array}$ \\
\hline $\begin{array}{l}\text { Epstein and } \\
\text { O'Halloran } \\
\text { (1999) }\end{array}$ & $\begin{array}{l}\text { Delegating powers: A } \\
\text { transaction cost politics } \\
\text { approach to policy making } \\
\text { under separate powers }\end{array}$ & $\begin{array}{l}\text { This book studies the mechanism of delegating powers from the } \\
\text { transaction cost politics approach, and it includes a chapter that } \\
\text { focused on the theory of TCP. It takes some lessons from the theory } \\
\text { of the firm, it shows several differences and similarities between } \\
\text { economics and politics, and it analyses the political hold-up problem. }\end{array}$ \\
\hline $\begin{array}{l}\text { Williamson } \\
\text { (1999) }\end{array}$ & $\begin{array}{l}\text { Public and Private } \\
\text { Bureaucracies: A Transaction } \\
\text { Cost Economics Perspective }\end{array}$ & $\begin{array}{l}\text { This paper explains how public bureaucracy is well suited to } \\
\text { some transactions and poorly suited to others. It compares the } \\
\text { efficacy of public and private bureaucracy and concludes that } \\
\text { there is an efficiency place for public bureaucracy through the } \\
\text { lens of transaction cots analysis. }\end{array}$ \\
\hline $\begin{array}{l}\text { Spiller and } \\
\text { Tommasi } \\
\text { (2003) }\end{array}$ & $\begin{array}{l}\text { The institutional foundations } \\
\text { of public policy: A } \\
\text { transactions approach with } \\
\text { applications to Argentina }\end{array}$ & $\begin{array}{l}\text { The paper develops a transactions theory to understand the ways } \\
\text { in which political institutions affect the political transactions, and } \\
\text { it argues that Argentina is a case in which the functioning of } \\
\text { political institutions has inhibited the capacity to undertake } \\
\text { efficient intertemporal political exchanges. }\end{array}$ \\
\hline Dixit (2003) & $\begin{array}{l}\text { Some lessons from } \\
\text { Transaction Cost Politics for } \\
\text { Less Developed Countries }\end{array}$ & $\begin{array}{l}\text { This paper examines some implications of TCP for less-developed } \\
\text { countries considering policy reform. It considers that success } \\
\text { requires reform of the rules and institutions which govern the } \\
\text { strategic interaction of the participants in the political game. }\end{array}$ \\
\hline $\begin{array}{l}\text { Spiller and } \\
\text { Tommasi } \\
(2007)\end{array}$ & $\begin{array}{l}\text { The institutional foundations } \\
\text { of Public Policy in Argentina. } \\
\text { A transaction cost approach }\end{array}$ & $\begin{array}{l}\text { This book develops a framework for the comparative analysis of } \\
\text { the impact of political institutions on public policies making use } \\
\text { of TCP. The core of the approach is the idea that public policy is } \\
\text { an agreement (transaction) among policy makers and it points } \\
\text { out the intertemporal approach to policy-making. The book } \\
\text { analyses the workings of the political institutions in Argentina } \\
\text { (Congress, Federalism, Supreme Court, Bureaucracy). }\end{array}$ \\
\hline Lake (2009) & $\begin{array}{l}\text { Hobbesian Hierarchy: The } \\
\text { Political Economy of Political } \\
\text { Organization }\end{array}$ & $\begin{array}{l}\text { This paper explains political hierarchy and integrates relational } \\
\text { contracting theory with other alternative approaches. }\end{array}$ \\
\hline
\end{tabular}


Table 2: Transaction Costs in Political Exchange and Governance: Other Contributions

Note: This Table incorporates papers that made contributions on political transaction costs from diverse perspectives. Their authors would not necessarily brand themselves as new institutionalists.

\begin{tabular}{|c|c|c|}
\hline $\begin{array}{l}\text { Author } \\
\text { (Year) }\end{array}$ & Title & Topic \\
\hline Twight (1994) & $\begin{array}{l}\text { Political Transaction- } \\
\text { Cost Manipulation. An } \\
\text { integrating theory }\end{array}$ & $\begin{array}{l}\text { This paper develops a model of government manipulation of politically } \\
\text { relevant transaction costs, and presents a taxonomy that classifies } \\
\text { several forms of governmental transaction-cost manipulation. }\end{array}$ \\
\hline $\begin{array}{l}\text { Patasksnik } \\
\text { (1996) }\end{array}$ & $\begin{array}{l}\text { The contractual natural } \\
\text { of budgeting: A transac- } \\
\text { tion cost perspective on } \\
\text { the design of budgeting } \\
\text { institutions }\end{array}$ & $\begin{array}{l}\text { This paper provides an overview of transaction cost theory and its im- } \\
\text { plications for the design of budgeting institutions. It contrasts the be- } \\
\text { havioural premises of the transactional approach with those of more } \\
\text { traditional budgetary theories and examines whether commitment } \\
\text { and agency costs have structured budget actors' institutional choices. }\end{array}$ \\
\hline $\begin{array}{l}\text { Weber } \\
\text { (1997) }\end{array}$ & $\begin{array}{l}\text { Hierarchy Amidst } \\
\text { Anarchy: A Transaction } \\
\text { Costs Approach to } \\
\text { International Security } \\
\text { Cooperation }\end{array}$ & $\begin{array}{l}\text { This paper provides an interest-based explanation for hierarchy in inter- } \\
\text { national politics. The key to understanding countries' international insti- } \\
\text { tutional choices is in focusing on transaction costs. It tests the theory } \\
\text { via the case study of the creation of a European Defense Community. }\end{array}$ \\
\hline $\begin{array}{l}\text { Jones and } \\
\text { Hudson } \\
\text { (1998) }\end{array}$ & $\begin{array}{l}\text { The role of political par- } \\
\text { ties: An analysis based } \\
\text { on transaction costs }\end{array}$ & $\begin{array}{l}\text { This paper explores the proposition that political parties reduce the } \\
\text { transaction costs of electoral participation. Political parties reduce vot- } \\
\text { ers' information costs. }\end{array}$ \\
\hline $\begin{array}{l}\text { Laffont and } \\
\text { Martimont } \\
\text { (1998) }\end{array}$ & $\begin{array}{l}\text { Transaction costs, insti- } \\
\text { tutional design and the } \\
\text { separation of powers }\end{array}$ & $\begin{array}{l}\text { This theoretical paper discusses how an institutional design relying on } \\
\text { separation of powers among specialized agencies may improve policy } \\
\text { outcomes. The choice of specialized agencies is better because it in- } \\
\text { creases the overall transaction costs of capture. }\end{array}$ \\
\hline $\begin{array}{l}\text { Hindmoor } \\
\text { (1998) }\end{array}$ & $\begin{array}{l}\text { The importance of be- } \\
\text { ing trusted: Transaction } \\
\text { costs and policy net- } \\
\text { work theory }\end{array}$ & $\begin{array}{l}\text { This paper develops policy network theory using a transactional ap- } \\
\text { proach. Policy communities develop and survive because they reduce } \\
\text { transaction costs that would otherwise threaten the exchange of re- } \\
\text { sources between government and pressure groups. }\end{array}$ \\
\hline $\begin{array}{l}\text { Gallego- } \\
\text { Calderón } \\
\text { (1998) }\end{array}$ & $\begin{array}{l}\text { Institutional design in } \\
\text { the public sector: the } \\
\text { role of political transac- } \\
\text { tion costs }\end{array}$ & $\begin{array}{l}\text { This paper studies the extent to which political transaction costs may } \\
\text { influence the decisions that politicians make when designing public } \\
\text { sector organisational arrangements. It points out that political } \\
\text { transactions are mediated though relations of public authority. }\end{array}$ \\
\hline $\begin{array}{l}\text { Estache and } \\
\text { Martimort } \\
\text { (1999) }\end{array}$ & $\begin{array}{l}\text { Politics, transaction } \\
\text { costs and the design of } \\
\text { regulatory institutions }\end{array}$ & $\begin{array}{l}\text { This paper studies the design of regulatory institutions from a } \\
\text { transaction costs approach. Structures and processes will affect } \\
\text { regulatory outcomes, by which the paper analyses the role of } \\
\text { transaction costs in the government organizational structure. }\end{array}$ \\
\hline $\begin{array}{l}\text { Majone } \\
\text { (2001) }\end{array}$ & $\begin{array}{l}\text { Nonmajoritarian Institu- } \\
\text { tions and the Limits } \\
\text { of Democratic Gover- } \\
\text { nance: A Political Trans- } \\
\text { action-Cost Approach }\end{array}$ & $\begin{array}{l}\text { This paper shows that delegation of powers to nonmajoritarian } \\
\text { institutions is best understood as a means of reducing certain political } \\
\text { transaction costs. It argues that the fiduciary principle should be } \\
\text { recognised as the central element in the governance structure of } \\
\text { nonmajoritarian institutions. }\end{array}$ \\
\hline $\begin{array}{l}\text { Murshed } \\
\text { (2001) }\end{array}$ & $\begin{array}{l}\text { Transaction Cost } \\
\text { Politics, Institutions for } \\
\text { Commitment and } \\
\text { Rent-Seeking }\end{array}$ & $\begin{array}{l}\text { This paper addresses the issues of commitment, compromise and rent- } \\
\text { seeking, all of which are relevant to institutional design and the formulation } \\
\text { of policies. It assumes some foundations from transaction cost politics. }\end{array}$ \\
\hline
\end{tabular}




\begin{tabular}{|c|c|c|}
\hline $\begin{array}{l}\text { Jones and } \\
\text { Hudson } \\
\text { (2001) }\end{array}$ & $\begin{array}{l}\text { Political Parties, Politi- } \\
\text { cal Integrity and Public } \\
\text { Policy: A transaction } \\
\text { costs approach }\end{array}$ & $\begin{array}{l}\text { This paper presents a transaction costs theory of political parties. It } \\
\text { points that if voters reduce transaction costs by relying on party signal, } \\
\text { politicians have an incentive to maintain party reputation. }\end{array}$ \\
\hline $\begin{array}{l}\text { Acemoglu } \\
(2003)\end{array}$ & $\begin{array}{l}\text { Why not a political } \\
\text { Coase Theorem? Social } \\
\text { Conflict, commitment } \\
\text { and politics }\end{array}$ & $\begin{array}{l}\text { This paper discusses various approaches to political economy and devel- } \\
\text { ops the argument that there are strong empirical and theoretical grounds } \\
\text { for believing that inefficient policies and institutions are prevalent. }\end{array}$ \\
\hline $\begin{array}{l}\text { Ter Bogt } \\
\text { (2003) }\end{array}$ & $\begin{array}{l}\text { A Transaction Cost Ap- } \\
\text { proach to the Autono- } \\
\text { mization of Government } \\
\text { Organizations: A Political } \\
\text { Transaction Cost Frame- } \\
\text { work Confronted with Six } \\
\text { cases of autonomization } \\
\text { in the Netherlands }\end{array}$ & $\begin{array}{l}\text { This paper applies a transaction cost framework to politically governed } \\
\text { organizations. The results of exploratory case research into six govern- } \\
\text { ment organizations in the Netherlands suggest that such factors as } \\
\text { bounded rationality, opportunism, political efficiency, and social institu- } \\
\text { tions may have played an important part in the autonomization of the } \\
\text { organizations involved. }\end{array}$ \\
\hline $\begin{array}{l}\text { Berggreen } \\
\text { and Karlson } \\
\text { (2003) }\end{array}$ & $\begin{array}{l}\text { Constitutionalism, } \\
\text { division of power and } \\
\text { transaction costs }\end{array}$ & $\begin{array}{l}\text { This paper expands the framework of Buchanan and Tullock (1962), } \\
\text { and it argues that a division of power can be beneficial and that it } \\
\text { is not necessarily the case that a division of power does entail high } \\
\text { transaction costs. }\end{array}$ \\
\hline $\begin{array}{l}\text { Henisz and } \\
\text { Zelner (2004) }\end{array}$ & $\begin{array}{l}\text { Explicating political haz- } \\
\text { ards and safeguards: a } \\
\text { transaction cost politics } \\
\text { approach }\end{array}$ & $\begin{array}{l}\text { The paper applies the logic of comparative institutional analysis to } \\
\text { the question of the governance of the relationship between private } \\
\text { investors and the government. The paper identifies political hazards } \\
\text { as a crucial determinant of the choice of political governance and the } \\
\text { transactional attributes that give rise to such hazards. }\end{array}$ \\
\hline $\begin{array}{l}\text { Wood and } \\
\text { Bohte (2004) }\end{array}$ & $\begin{array}{l}\text { Political transaction } \\
\text { costs and the politics of } \\
\text { administrative design }\end{array}$ & $\begin{array}{l}\text { The paper proposes a political transaction cost theory of the politics of } \\
\text { administrative design. It assumes that the enacting coalition alters politi- } \\
\text { cal transaction costs to optimize expected benefits. The paper evaluates } \\
\text { the theory using data for the designing US administrative agencies. }\end{array}$ \\
\hline $\begin{array}{l}\text { Caballero, } \\
\text { Caballero } \\
\text { and Losada } \\
\text { (2006) }\end{array}$ & $\begin{array}{l}\text { Credibility, Rules and } \\
\text { Power in the European } \\
\text { Union Institutions: a } \\
\text { Transactional Analysis } \\
\text { of the Stability and } \\
\text { Growth Pact }\end{array}$ & $\begin{array}{l}\text { This paper opened the "black box" of the European Union institutions } \\
\text { and analyses the problem of credibility in the commitment of the } \\
\text { Stability and Growth pact, which constituted a formal rule that tried } \\
\text { to enforce budgetary discipline on the European States. Compliance } \\
\text { with this contract could be ensured by a "third-party enforcement" or } \\
\text { an interest in reputational capital, but some countries failed to comply } \\
\text { with the ruling and managed to avoid the application of sanctions. }\end{array}$ \\
\hline Ruiter (2005) & $\begin{array}{l}\text { Is Transaction Cost } \\
\text { Economics Applicable } \\
\text { to Public Governance? }\end{array}$ & $\begin{array}{l}\text { This paper studies the applicability of transactional analysis to the pu- } \\
\text { blic sphere with the use of institutional legal theory. An attempt is ma- } \\
\text { de at solving some fundamental problems concerning the applicability } \\
\text { of transaction cost economics to public governance. }\end{array}$ \\
\hline $\begin{array}{l}\text { Sorensen } \\
\text { (2006) }\end{array}$ & $\begin{array}{l}\text { Local government con- } \\
\text { solidations: The impact } \\
\text { of political transaction } \\
\text { costs }\end{array}$ & $\begin{array}{l}\text { This paper studies the effect of political transaction costs on the consolida- } \\
\text { tion of local authorities for the case of the Norwegian local governments. }\end{array}$ \\
\hline $\begin{array}{l}\text { Caballero } \\
\text { (2011) }\end{array}$ & $\begin{array}{l}\text { Institutional Founda- } \\
\text { tions, Committee } \\
\text { System and Amateur } \\
\text { Legislators in the } \\
\text { Governance of the } \\
\text { Spanish Congress: An } \\
\text { Institutional Compara- } \\
\text { tive Perspective (USA, } \\
\text { Argentina, Spain) }\end{array}$ & $\begin{array}{l}\text { This paper continues the research programme of Weingast and Marshall } \\
\text { (1988) to compare different models of Congress governance in Spain, } \\
\text { Argentina and USA. The traditional industrial organization of the US Con- } \\
\text { gress is based on a candidate-centered electoral rules, strong commit- } \\
\text { tees and professional legislators in a presidential system. The Argentine } \\
\text { Congress is based on party-centered electoral rules, weak committees } \\
\text { and amateur legislators in a presidential system. The Spanish case is } \\
\text { similar to the Argentine model but in a parliamentary system. }\end{array}$ \\
\hline
\end{tabular}




\begin{tabular}{|l|l|l|}
\hline $\begin{array}{l}\text { Caballero } \\
\text { and Arias } \\
(2013)\end{array}$ & $\begin{array}{l}\text { Transaction Cost Politics } \\
\text { in the Map of the New } \\
\text { Institutionalism }\end{array}$ & $\begin{array}{l}\text { This paper shows the different types of new institutionalism and pre- } \\
\text { sents Transaction Cost Politics in the map that incorporates all those } \\
\text { types of institutionalisms in social sciences. }\end{array}$ \\
\hline $\begin{array}{l}\text { Baccini } \\
(2014)\end{array}$ & $\begin{array}{l}\text { Cheap talk: Transaction } \\
\text { costs, quality of } \\
\text { institutions, and trade } \\
\text { agreements }\end{array}$ & $\begin{array}{l}\text { This paper defends that the quality of institutions raises the quantity and } \\
\text { the quality of information available to potential member states during } \\
\text { the bargaining phase of a trade agreement. In turn, this inflow of infor- } \\
\text { mation reduces the negotiation period of an agreement and, in doing so, } \\
\text { dampens the transaction costs associated with it. As a result, countries } \\
\text { with good institutions are more likely to form trade agreements. }\end{array}$ \\
\hline $\begin{array}{l}\text { Krutilla and } \\
\text { Alexeev } \\
(2014)\end{array}$ & $\begin{array}{l}\text { The Political Transaction } \\
\text { Costs and Uncertainties } \\
\text { of Establishing } \\
\text { Environmental Rights }\end{array}$ & $\begin{array}{l}\text { This paper deals with the costs and uncertainties associated with es- } \\
\text { tablishing the right to use resources and models the political process } \\
\text { around the rights establishment. The model is solved to give unique } \\
\text { Nash equilibria for the transaction costs of lobbying and for the prob- } \\
\text { ability of the policy's political success. }\end{array}$ \\
\hline $\begin{array}{l}\text { Gilligan } \\
(2014)\end{array}$ & $\begin{array}{l}\text { The transactions costs } \\
\text { approach to interna- } \\
\text { tional institutions }\end{array}$ & $\begin{array}{l}\text { This paper studies the role of transaction costs in the creation of inter- } \\
\text { national institutions and departures from the decentralized cooperation } \\
\text { theory to incorporate transaction costs and international institutions. }\end{array}$ \\
\hline
\end{tabular}

